\title{
Antimicrobial Effect of Eucalyptus Oil as a Root Canal Filling Material for Primary Teeth in Comparison with other Filling Materials against $C$. albicans and Streptococcus spp.
}

\author{
Luma A. Alashbal ${ }^{*}(\mathbb{D})$, Zainab Juma Jafar ${ }^{1} \mathbb{D}$ and Zainab A. Aldhaher ${ }^{2} \mathbb{D}$ \\ ${ }^{1}$ Department of Pediatric and Preventive Dentistry, College of Dentistry, University of Baghdad, Baghdad, Iraq. \\ ${ }^{2}$ Department of Basic Science, College of Dentistry, University of Baghdad, Baghdad, Iraq.
}

\begin{abstract}
Microbial invasion is the most common cause of pulpal necrosis. Therefore, irrigation and obturation of primary teeth with antimicrobial materials is quite necessary to increase the success of endodontic treatment. To compare the antimicrobial effect of mixture of zinc oxide eucalyptus oil with zinc oxide eugenol, and Metapex. An in vitro antimicrobial activity was estimated using agar diffusion method. $C$. albicans and Streptococcus spp. were isolated and identified from necrotic pulp of primary root, then they were spread on Muller Hinton agar. Holes of $6 \mathrm{~mm}$ were punched into the agar plates and filled with the selected materials. The diameter of inhibition zones was measured after overnight incubation at $37^{\circ} \mathrm{C}$. The statistical analysis was done using One Way ANOVA test with Tukey or Dunnett's T3 as a post hoc tests at level of significant 0.05 . The inhibition zones of zinc oxide eucalyptus mixture and zinc oxide eugenol against $C$. albicans and Streptococci were almost near to each other with statistically nonsignificant differences. While Metapex showed lowest inhibition zones with highly significant difference when compared to zinc oxide eucalyptus mixture and zinc oxide eugenol against both microorganisms. Zinc oxide eucalyptus mixture showed almost similar antimicrobial effect to zinc oxide eugenol, while Metapex revealed lowest antimicrobial effect.
\end{abstract}

Keywords: antimicrobial, obturations, eucalyptus oil, primary teeth.

*Correspondence: lumaalashbal2@gmail.com; +9647801879936

(Received: 12 May 2019; accepted: 19 June 2019)

Citation: Luma A. Alashbal, Zainab Juma Jafar and Zainab A. Aldhaher, Antimicrobial Effect of Eucalyptus Oil as a Root Canal Filling Material for Primary Teeth in Comparison with other Filling Materials against C. albicans and Streptococcus spp., J Pure Appl Microbiol., 2019; 13(3): 1537-1542. https://doi.org/10.22207/JPAM.13.3.25

C The Author(s) 2019. Open Access. This article is distributed under the terms of the Creative Commons Attribution 4.0 International License which permits unrestricted use, sharing, distribution, and reproduction in any medium, provided you give appropriate credit to the original author(s) and the source, provide a link to the Creative Commons license, and indicate if changes were made. 


\section{INTRODUCTION}

There are about 700 bacterial species compromising normal oral microflora and some of these microorganisms have a pathogenic potential ${ }^{1}$. Microbial colonization in the pulp through dental caries have been considered as major responsible element of pulpal and periapical disease ${ }^{2}$. The complex oral microbiota can infect not only root canal space, but also colonize the isthmus, accessory canals, ramification of apical delta, apical foramen and dentinal tubules, which cannot be simply removed even after chemomechanical preparations ${ }^{3}$. Therefore, irrigation with antimicrobial material and obturation with known antimicrobial property paste is quite necessary to increase the chance of root canal treatment success rate ${ }^{4}$.

Streptococcus spp. are Gram-positive cocci in chains and pairs, facultative anaerobes, that have been isolated from all parts of the oral cavity and constitutes huge percentage of the resident culturable oral microbiota ${ }^{1}$. Some studies reported their presence in high percentage in endodontic infections of necrotic deciduous teeth $^{5}$.

Yeasts and specifically C. albicans have been constituted less than $1 \%$ of the root canal flora, while their proportion is about $7-18 \%$ in the infected endodontic canals, which is most frequently detected in persistent apical periodontitis 6 .

It has been found that $C$. albicans and oral Streptococcus coinfection can intensify the virulence of caries, endodontic infections and more serious oropharyngeal infections ${ }^{7}$.

Zinc oxide eugenol and calcium hydroxide with iodoform (Metapex) has been widely used obturation material for deciduous teeth. Nevertheless, none of these materials consider ideal $^{8}$.

Eucalyptus oil contains a valuable medicinally and pharmacologically influential chemicals, that is already been used in many aspects of medicine as an anti-inflammatory, antimicrobial, antioxidative, antihistaminic, antiseptic agent etc. ${ }^{9}$. Considering these facts, several attempts had been carried out to use eucalyptus oil in various dental aspects ${ }^{10}$. As there were no previous studies about the use of eucalyptus oil as root canal filling material in primary teeth, the current study aimed to investigate the first step of introduction of this material as root canal filling material by estimation of antimicrobial activity of Zinc oxide eucalyptus paste compared to traditionally used obturation materials for primary teeth as zinc oxide eugenol paste and Metapex.

\section{MATERIALS AND METHODS}

All microbial specimens were obtained from 21 children aged 3-8 yrs., of both sexes, and all of the patient's guardian were given a consent form before performing of the sampling procedure.

The patients were presented with necrotic deciduous teeth with or without periapical lesion, selected randomly regardless the cause of pulpal or periapical pathology.

The patients with the following criteria were included ${ }^{5}$ :

1. Children with no systemic disease.

2. Patient did not take any antibiotics for at least 4. Weeks prior to sampling procedure.

3. Teeth had at least one necrotic root canal.

4. Root with no resorption or at least less than $2 / 3$ of the root resorbed.

5. Crowns weren't broken for proper isolation.

\section{Isolation procedure}

After disinfection of the oral cavity with $2 \%$ chlorhexidine digluconate mouth wash for $1 \mathrm{~min}$, isolation of the selected tooth was done by using rubber dam. Then proper unobstructed access opening was performed till obtaining clear vision of root canals entrance. The selected canals for sampling procedure were anterior teeth, distal canal of lower primary molar and palatal canal for upper primary molar, a sterile paper point was inserted at most apical extent in the canal up to $60 \mathrm{sec}$, the saturated paper point was immediately transferred into sterile tube containing $3 \mathrm{ml}$ brain heart infusion broth (BHI-B) and send for microbiological analysis. The BHI-B tubes were incubated at $37^{\circ} \mathrm{C}$ for $24 \mathrm{hrs}$. and with aid of sterile swab impregnated in the broth, inoculation was done by streaking method into (1) Blood agar media for Streptococcus spp. (2) Sabauraud dextrose agar, for growing of $C$. albicans.

All petri plates were incubated aerobically at $37^{\circ} \mathrm{C}$ for 24 hours ${ }^{5,11}$. The identification of colonies was done based on gram staining, colony 
characters and biochemical reaction.

Filling materials

In this study the oil of $E$. globulus (plant therapy ${ }^{\circledast}$ essential oil, USA) was mixed with zinc oxide and compared with zinc oxide eugenol paste and Metapex ${ }^{\circledR}$ (Meta Biomed Co. Ltd, Korea). Vaseline ${ }^{\circledR}$ was used as a negative control. All powder and liquid ratio were standardized in consistent with formulae described by Tchaou et al. and Thosar et al. ${ }^{12,13}$. A quantity of powder $0.2 \mathrm{gm}$ was blended with $0.07 \mathrm{cc}$ oil. The materials were mixed on sterile dry glass slab, using cement spatula at room temperature. Just before it is assayed for agar diffusion method.

\section{Agar diffusion method}

The standard agar diffusion assay was used for sensitivity testing. The turbidity of brain heart infusion broth suspension was adjusted to $0.5 \mathrm{McFarland}$ standard. A sterile cotton swab dipped into the broth tube was swabbed 3 times to ensure equal dispersion of the inoculum on Muller Hinton agar plate. Then four wells $(6 \mathrm{~mm}$ in diameter) were drilled into each $\mathrm{MH}$ plate in equal distant from each other by the aid of sterile cork borer, then filled with the test materials and incubated at $37^{\circ} \mathrm{C}$ for $24 \mathrm{hrs}$. The inhibition zones diameter was calibrated in millimeter by using Boley gauge ${ }^{14}$.

\section{Statistical analysis}

Data of antimicrobial activity were analyzed statistically using Shapiro- Wilk test to test the normality and One-Way Analysis of Variance ANOVA with Tukey Honestly Significant Difference (Tukey HSD) or Dunnett's T3 as a post hoc tests at significant level of 0.05 using SPSS version 21 software. Levene statistic was also used to test the homogeneity of variance among groups.

\section{RESULTS}

All data revealed normally distributed sample with statistically non-significant differences, as presented in table (1) and (2).

The results showed that Zinc oxide eugenol had the highest mean of inhibition zone against Streptococcus spp. followed by Zinc oxide eucalyptus, while Metapex showed the lowest mean of inhibition zone, with highly significant difference among the tested groups, as presented in table (3).

Multiple comparisons among obturation materials against Streptococcus spp. using Tukey test as post hoc revealed highly significant

Table 1. Normality test of Streptococcus spp.

\begin{tabular}{lcccc}
\hline \multirow{2}{*}{ Groups } & \multicolumn{4}{c}{ Shapiro-Wilk } \\
\cline { 2 - 4 } & Statistic & $\mathrm{df}$ & Sig. \\
\hline $\begin{array}{l}\text { Zinc oxide } \\
\text { eucalyptus }\end{array}$ & .850 & 10 & .058 & \\
$\begin{array}{l}\text { Zinc oxide } \\
\text { eugenol }\end{array}$ & .888 & 10 & .161 & NS \\
Metapex & .911 & 10 & .286 & \\
\hline
\end{tabular}

Table 2. Normality test of $C$. albicans

\begin{tabular}{lcccc}
\hline \multirow{2}{*}{ Groups } & \multicolumn{4}{c}{ Shapiro-Wilk } \\
\cline { 2 - 4 } & Statistic & $\mathrm{df}$ & Sig. \\
\hline $\begin{array}{l}\text { Zinc oxide } \\
\text { eucalyptus }\end{array}$ & .901 & 10 & .227 & \\
$\begin{array}{l}\text { Zinc oxide } \\
\text { eugenol }\end{array}$ & .882 & 10 & .138 & NS \\
\begin{tabular}{l} 
Metapex \\
\hline
\end{tabular} & .850 & 10 & .058 & \\
\hline
\end{tabular}

Table 3. Mean value of inhibition zones of obturation materials against Streptococcus spp. in millimeter

\begin{tabular}{lccccccc}
\hline Groups & $\mathrm{N}$ & $\begin{array}{c}\text { Mean } \\
(\mathrm{mm})\end{array}$ & $\pm S D$ & Minimum & Maximum & $\mathrm{F}$ & P value \\
\hline $\begin{array}{l}\text { Zinc oxide } \\
\text { eucalyptus }\end{array}$ & 10 & 16.400 & 2.366 & 11.000 & 19.000 & & \\
$\begin{array}{l}\text { Zinc oxide } \\
\text { eugenol }\end{array}$ & 10 & 17.300 & 3.743 & 13.000 & 25.000 & 17.826 & .000 \\
$\begin{array}{l}\text { Metapex } \\
\text { Metapen }\end{array}$ & 10 & 8.000 & 4.967 & .000 & 16.000 & & \\
\hline
\end{tabular}

Levene statistics $=1.662, \mathrm{p}$ value $=0.209[\mathrm{NS}]$ 
difference among all tested groups, except between Zinc oxide eucalyptus and Zinc oxide eugenol which revealed a non-significant difference, as presented in table (4).

The results showed that Zinc oxide eucalyptus had the highest mean of inhibition zone against $C$. albicans followed by Zinc oxide eugenol, while Metapex showed the lowest mean of inhibition zone, with highly significant difference among the tested groups, as presented in table (5).

Multiple comparisons among obturation groups against $C$. albicans using Dunnett T3 test as post hoc reveal highly significant difference between Metapex and zinc oxide eucalyptus, and highly significant difference between Metapex and
Table 4. Multiple Comparisons of antibacterial effect of various filling materials against Streptococcus spp.

\begin{tabular}{|c|c|c|c|}
\hline \multicolumn{4}{|c|}{$\begin{array}{c}\text { Multiple Comparisons } \\
\text { Dependent Variable:Streptococcus } \\
\text { Tukey HSD }\end{array}$} \\
\hline (I) Groups & (J) Groups & $\begin{array}{l}\text { Mean } \\
\text { Difference } \\
(I-J)\end{array}$ & $\begin{array}{c}P \\
\text { value }\end{array}$ \\
\hline \multirow[t]{2}{*}{$\begin{array}{l}\text { Zinc oxide } \\
\text { eucalyptus }\end{array}$} & $\begin{array}{c}\text { Zinc oxide } \\
\text { eugenol }\end{array}$ & -.900 & $.860[N S]$ \\
\hline & Metapex & 8.400 & $.000[\mathrm{HS}]$ \\
\hline $\begin{array}{l}\text { Zinc oxide } \\
\text { eugenol }\end{array}$ & Metapex & 9.300 & $.000[\mathrm{HS}]$ \\
\hline
\end{tabular}

Table 5. Mean value of inhibition zones of obturation materials against $C$. albicans in millimeter

\begin{tabular}{lccccccc}
\hline Groups & $\mathrm{N}$ & $\begin{array}{c}\text { Mean } \\
(\mathrm{mm})\end{array}$ & $\pm S D$ & Minimum & Maximum & $\mathrm{F}$ & $\begin{array}{c}\mathrm{P} \\
\text { value }\end{array}$ \\
\hline $\begin{array}{l}\text { Zinc oxide } \\
\text { eucalyptus }\end{array}$ & 10 & 31.200 & 3.490 & 24.000 & 35.000 & & \\
$\begin{array}{l}\text { Zinc oxide } \\
\text { eugenol } \\
\text { Metapex }\end{array}$ & 10 & 30.200 & 3.259 & 27.000 & 37.000 & 77.222 & 0.000 \\
\hline
\end{tabular}

Levene statistics $=6.699, \mathrm{p}$ value $=0.004[\mathrm{HS}]$

zinc oxide eugenol, while there was non-significant difference between Zinc oxide eucalyptus and Zinc oxide eugenol, as presented in table (6).

\section{DISCUSSION}

E. globulus, also called blue gum, grows widely in various countries in the world, and known for its massive medicinal utilization ${ }^{15}$. The antimicrobial activity of E. globulus oil is related the mixture of monoterpenes and oxygenated monoterpenes mainly 1,8 - cineole ${ }^{16}$. The eucalyptus oil showed good inhibitory effect on both tested Microbes and these outcomes are in agreement with previous studies of Ait-Ouazzou et al. and Bachheti ${ }^{17,18}$. However, as there was no previous study of using eucalyptus oil with $\mathrm{ZnO}$ powder as an obturation material for primary teeth, the comparison of this mixture with other obturation materials is not available.

In general, the hydrophobicity of essential oil permits lipids partition of cell membrane and mitochondria, rendering them more permeable
Table 6. Multiple Comparisons of antibacterial effect of various filling materials against $C$. albicans

\begin{tabular}{|c|c|c|c|}
\hline \multicolumn{4}{|c|}{$\begin{array}{c}\text { Multiple Comparisons } \\
\text { Dependent Variable: } \text { C. albicans } \\
\text { Dunnett T3 }\end{array}$} \\
\hline (I) Groups & (J) Groups & $\begin{array}{l}\text { Mean } \\
\text { Difference } \\
(I-J)\end{array}$ & Sig. \\
\hline \multirow[t]{2}{*}{$\begin{array}{l}\text { Zinc oxide } \\
\text { eucalyptus }\end{array}$} & $\begin{array}{c}\text { zinc oxide } \\
\text { eugenol }\end{array}$ & 1.00 & $.880[N S]$ \\
\hline & Metapex & 23.800 & $.000[\mathrm{HS}]$ \\
\hline $\begin{array}{l}\text { Zinc oxide } \\
\text { eugenol }\end{array}$ & Metapex & 22.800 & $.000[\mathrm{HS}]$ \\
\hline
\end{tabular}

leading to protein leakage of both the Gram positive and Gram-negative bacteria ${ }^{19}$.

In the current study, $C$. albicans was more sensitive to eugenol and eucalyptus content of the tested materials than $\mathrm{G}+\mathrm{ve}$ bacterial, this can be interpreted by structural and metabolic variations 
that exist prokaryotic (bacteria) and eukaryotic cells (yeasts) and the abundance of the active antimicrobial constituents in each oil ${ }^{20}$.

Zinc oxide eugenol (ZOE) has been a material of choice and one of the most commonly used obturation material for deciduous teeth. The main drawback of ZOE related to its slow resorption rate compared to physiological root resorption ${ }^{8}$. The mode of antimicrobial activity is mainly attributed to eugenol that consider the active component of clove oil ${ }^{13}$. The statistical results of Zinc oxide eugenol on both microorganisms agrees with previous studies of Gomes et al. and Navit et $a l^{21,22}$, proving eugenol containing filling material were more superior in inhibition microorganisms. Nonetheless, these were not the outcomes of other researchers Tchaou et al. and Gonnalves et al. ${ }^{12,11}$ as their findings showed medium or limit antimicrobial effect.

Numerous publications had documented the anti-microbial effect of premixed $\mathrm{Ca}(\mathrm{OH})_{2}$ and iodoform (Metapex). The basic principle of action of antimicrobial action related to highly alkalinity of $\mathrm{Ca}(\mathrm{OH})_{2}$ that is about $12.5-12.8$, and its effect begins with the ionic dissociation into $\mathrm{Ca}^{2+}$ and $\mathrm{OH}$ - ions in an aqueous environment ${ }^{23}$. lodoform reaction arises from liberation of iodine, which is highly reactive causing proteins precipitation and essential enzymes oxidation ${ }^{24}$. However, some studies found that $\mathrm{Ca}(\mathrm{OH})_{2}$ component of Metapex interfere with the antiseptic ability of dyadic combinations of endodontic medicaments ${ }^{22,23}$.

The weak effect of Metapex against $C$. albicans could be because $C$. albicans can survive in broad range of $\mathrm{pH}$ values so the high alkalinity of $\mathrm{Ca}(\mathrm{OH})_{2}$ may have low impact on $C$. albicans, besides $\mathrm{Ca}(\mathrm{OH})_{2}$ might implement the $\mathrm{Ca}^{2+}$ ions required for morphogenesis and growth of Candida spp. ${ }^{24}$.

\section{CONCLUSION}

This new material, zinc oxide eucalyptus showed almost similar antimicrobial effect Zinc oxide eugenol, while Metapex revealed lowest antimicrobial effect against tested microorganisms.

\section{ACKNOWLEDGEMENT}

None.

\section{CONFLICT OF INTEREST}

The authors declares that there is no conflict of interest.

\section{AUTHORS' CONTRIBUTION}

All authors have made substantial, direct and intellectual contribution to the work and approved it for publication.

\section{FUNDING}

None.

\section{DATA AVAILABILITY}

All datasets generated or analyzed during this study are included in the manuscript.

\section{ETHICS STATEMENT}

The research protocol was approved by the Institution's Ethical Committee and all of the patient's guardian were given a consent form before performing the sampling procedure.

\section{REFERENCES}

1. Marsh P.D., Lewis M.A.O., Rogers H., Williams D.W., Wilson M. Marsh and Martin's Oral Microbiology. 6TH ed. Elsevier Health Sciences UK; 2016.

2. Gutmann G.L., Manjarr's V. Historical and Contemporary Perspectives on the Microbiological Aspects of Endodontics. Dent. J., 2018; 6(49).

3. Yassin H.N., AL-Dahan Z.A., Hamod M.A. Evaluation of antibacterial effect of irrigant solutions (titanium tetra fluoride, green tea, sodium hypochlorite, normal saline) using real-time quantitative - polymerase chain reaction. J. Bagh College Dentistry, 2015; 27(3). https://doi.org/10.12816/0015048.

4. Prabhakar A.R., Sridevi E., Raju O.S., Satish V. Endodontic treatment of primary teeth using combination of antibacterial drugs: An in vivo study. J. Ind. Soc. Pedod. Prev. Dent., 2008; 26: 5-10.

5. Hegde A.M., Pallavi I. Prevalence of Selected Microorganisms in the Pulp Space of Human Deciduous Teeth with Irreversible Pulpitis. Journal of Endodontology, 2013; 25: 107-111.

6. Waltimo T.M., Haapasalo M., Zehnder M., Meyer J. Clinical aspects related to endodontic tract infections. Endodontic Topics, 2004; 9: 1-13. https://doi.org/10.1111/j.1601-1546.2004.00086.x.

7. Allison D.L., Willems H.M., Jayatilake J.A., Bruno V.M., Peters B.M., Shirtliff M.E. Candida-Bacteria Interactions: Their Impact on Human Disease. Microbiol Spectr., 2016; 3(4).

8. Rajasekhar S., Mallineni S.K., Nuvvula S. Obturating Materials Used for Pulpectomy in Primary Teeth- A Mini Review. J. Dent. Craniofac. Res.,2018; 3(1:3): 2576-392X. 
9. Adnan M. Bioactive potential of essential oil extracted from the leaves of Eucalyptus globulus (Myrtaceae). Journal of Pharmacognosy and Phytochemistry, 2019; 8(1): 213-216.

10. Agarwal R., Lakshmi T. Eucalyptus oil in dentistry: A mini Review. Int. J. Drug Dev. \& Res., 2013; 5(4): 58-61.

11. Gonnalves S.S., Silveira R.D., Miasato J.M., Oliveira L.M.C., Neves A.D. Antimicrobial activity of endodontic pastes on microorganisms present in root canals of necrotic primary molars. International Journal of Clinical Dentistry, 2015; 8(3): 213-223.

12. Tchaou W.S., Turng B.F., Minah G.E., Coll J.A. Inhibition of pure cultures of oral bacteria by root canal filling materials. Pediatric Dentistry, 1996; 18: 444-9.

13. Thosar N., Chandak M., Bhat M., Basak S. Antibacterial efficacy of zinc oxide pastes with various essential oils against Enterococcus faecalis and its comparison with zinc oxide eugenol paste. International Journal of Development Research, 2016; 6(12): 10663-10666.

14. Reddy S., Ramakrishna Y. Evaluation of Antimicrobial Efficacy of Various Root Canal Filling Materials Used in Primary Teeth: A Microbiological Study. J. Clin. Pediat.r Dent., 2007. 31(3): 195-199. https://doi.org/10.17796/ jcpd.31.3.t73r4061 424j2578.

15. Brown S.K., Garver W.S., Orlando R.A. 1,8-cineole: An Underappreciated Anti-inflammatory Therapeutic. J. Biomol. Res. Ther., 2017; 6(154). https://doi. org/10.4172/2167-7956.1000154.

16. Damjanoviт-Vratnica B., lakov T., ukoviт D., Damjanovic J. Antimicrobial Effect of Essential Oil Isolated from Eucalyptus globulus Labill. from Montenegro. Czech J. Food Sci., 2011; 29(3): 277-284. https://doi.org/10.17221/114/2009-CJFS.

17. Ait-Ouazzou A., Loren S., Bakkali M., Laglaoui A., Rota C., Herrera A. Chemical composition and antimicrobial activity of essential oils of Thymus algeriensis, Eucalyptus globulus and Rosmarinus officinalis from Morocco. J. Sci. Food Agric., 2011; 91(14): 2643-2651. https://doi.org/10.1002/jsfa.4505.

18. Bachheti R.K. Chemical composition and antibacterial activity of the essential oil from the leaves of Eucalyptus globulus collected from Haramaya University, Ethiopia. Der. Pharma. Chemica., 2015; 7(2): 209-214.

19. Oyedemi S., Mabinya L.V., Okoh A.I., Afolayan A.J. The proposed mechanism of bactericidal action of eugenol, A-terpineol and Yterpinene against Listeria monocytogenes, Streptococcus pyogenes, Proteus vulgaris and Escherichia coli. Afr. J. Biotechnol. 2009; 8(7):1280-1286.

20. Qanbar F.H., Al-Mizraqchi A.S. The Antimicrobial Effect of Aqueous and Alcoholic Extracts of Eucalyptus Leaves on Oral Mutans Streptococcus, Lactobacilli and Candida albicans (an in vitro study). J. Bag. Col. Dent., 2009; 21(2).

21. Gomes B.P.F.A., Pedroso J.A., Jacinto R.C., Vianna M.E., Ferraz C.C., Zaia A.A. In vitro evaluation of the antimicrobial activity of five root canal sealers. Braz. Dent. J., 2004; 15: 30-35. https://doi.org/10.1590/ S0103-64402004000100006.

22. Navit S., Jaiswal N., Khan S.A., Malhotra S., Sharma A., Mukesh, et al. Antimicrobial Efficacy of Contemporary Obturating Materials used in Primary Teeth- An In vitro Study. JCDR., 2016; 10(9): ZC09-ZC12. https://doi.org/10.7860/JCDR/2016/21883.8426.

23. Mohammadi Z., Shalavi S., Yazdizadeh M. Antimicrobial Activity of Calcium Hydroxide in Endodontics: A Review. Chonnam Med. J., 2012; 48: 133-140. https://doi.org/10.4068/cmj.2012.48.3.133.

24. Gautam S., Rajkumar B., Landge S.P., Dubey S., Nehete P., Boruah L.C. Antimicrobial efficacy of Metapex (Calcium hydroxide with lodoform formulation) at different concentrations against selected microorganisms - An In vitro study. Nepal Med. Coll. J., 2011; 13(4): 297-300E. 